\title{
KONDISI OPTIMUM PRODUKSI BIOETANOL DARI RUMPUT LAUT COKLAT (Sargassum duplicatum) MENGGUNAKAN Trichoderma viride DAN Pichia angophorae
}

\author{
Optimum Condition for Bioethanol Production \\ from Brown Seaweed (Sargassum duplicatum) using \\ Trichoderma viride and Pichia angophorae
}

\author{
Rodiah Nurbaya Sari ${ }^{*}$, Bagus Sediadi Bandol Utomo ${ }^{1}$, dan Armansyah H. Tambunan ${ }^{2}$ \\ ${ }^{1}$ Balai Besar Penelitian dan Pengembangan Pengolahan Produk dan Bioteknologi Kelautan dan Perikanan, \\ JI. K.S. Tubun Petamburan VI, Jakarta Pusat, Indonesia \\ ${ }^{2}$ Institut Pertanian Bogor, Bogor, Indonesia \\ * Korespondensi Penulis: rodiah_ns@yahoo.com
}

Diterima: 10 Januari 2013; Disetujui: 3 Desember 2014

\begin{abstract}
ABSTRAK
Rumput laut coklat Sargassum duplicatum selain banyak digunakan untuk industri makananminuman, kosmetik, dan farmasi juga dapat dimanfaatkan sebagai bahan baku untuk produksi bioetanol karena kandungan selulosanya tinggi dan ligninnya rendah. Tujuan dari penelitian ini adalah untuk mendapatkan kondisi optimum hidrolisis enzimatis untuk produksi bioetanol dari rumput laut coklat $S$. duplicatum dengan menggunakan kapang Trichoderma viride dan kondisi optimum untuk fermentasi menggunakan khamir Pichia angophorae sehingga diperoleh rendemen etanol yang tinggi. Metode yang digunakan terdiri dari beberapa tahap yaitu karakterisasi S. duplicatum, hidrolisis enzimatis dengan menggunakan $T$. viride, dan fermentasi dengan $P$. angophorae. Etanol kasar (crude) yang dihasilkan berdasarkan waktu optimum dari hidrolisis enzimatis dan fermentasi kemudian didistilasi untuk meningkatkan kadar etanolnya. Hasil penelitian menunjukkan bahwa waktu optimum untuk hidrolisis enzimatis adalah selama 4 hari pada suhu $28{ }^{\circ} \mathrm{C}$ dan $\mathrm{pH} 5,77$ dengan aktivitas enzim CMCase $3,48 \mathrm{IU} / \mathrm{ml}$ yang menghasilkan gula total 3,01 g/L dan gula pereduksi total $4,26 \mathrm{mg} / \mathrm{L}$. Sedangkan waktu optimum untuk fermentasi adalah selama 3 hari pada suhu $29^{\circ} \mathrm{C}$ dan $\mathrm{pH} 4,17$ dengan tingkat pertumbuhan (OD 600) $P$. angophorae 0,48; oksigen terlarut $13,4 \%$; konsentrasi $\mathrm{CO}_{2} 440,33 \mathrm{mg} / \mathrm{L}$ yang menghasilkan kadar etanol kasar 0,04 g/L. Proses distilasi dapat meningkatkan kadar etanol menjadi 10,50 g/ L.
\end{abstract}

KATA KUNCI: $\quad$ bioetanol, lignin, Sargassum duplicatum, Trichoderma viride, Pichia angophorae

\section{ABSTRACT}

Brown seaweed Sargassum duplicatum, which has been used widely for food and beverage, cosmetic, and pharmaceutical industries is also suitable as raw material for bioethanol production due to its high cellulose and low lignin content. The objectives of this experiment are to find out the optimum time for enzymatic hydrolysis for bioethanol production from S. duplicatum using fungi Trichoderma viride and optimum time for fermentation using yeast Pichia angophorae to obtain high yield of bioethanol. Experimental production method consists of characterization for S. duplicatum, enzymatic hydrolysis using T. viride and fermentation using P. angophorae. Crude ethanol produced based on optimum time of enzimatic hydrolysis and fermentation, was then distilled to increase ethanol content. Result showed that optimum time for enzymatic hydrolysis was 4 days at a temperature of $28^{\circ} \mathrm{C}$ and $\mathrm{pH} 5.77$ with CMCase activity of $3.48 \mathrm{IU} / \mathrm{ml}$ resulting in sugar total of $3.01 \mathrm{~g} / \mathrm{L}$ and reducing sugar total of $4.26 \mathrm{mg} / \mathrm{L}$. The optimum time for fermentation was 3 days at a temperature of $29^{\circ} \mathrm{C} ; \mathrm{pH} 4.17$ with cultivation rate (OD 600) of $\mathrm{P}$. angophorae of 0.48; dissolved oxygen of 13.4\%; and $\mathrm{CO}_{2}$ concentration of $440.33 \mathrm{mg} / \mathrm{L}$ resulting in crude ethanol content of $0.04 \mathrm{~g} / \mathrm{L}$. The distillation process increased up to $10.50 \mathrm{~g} / \mathrm{L}$ ethanol content.

KEYWORDS: bioetanol, lignin, Sargassum duplicatum, Trichoderma viride, Pichia angophorae 


\section{PENDAHULUAN}

Sargassum merupakan salah satu jenis rumput laut coklat di Indonesia yang bernilai ekonomis, memiliki umur panen yang relatif singkat, tersebar luas di perairan Indonesia (Kadi \& Atmadja, 1988) dengan potensi produksinya cukup tinggi namun produksinya masih banyak berasal dari hasil panen persediaan dari alami (Saputra et al., 2012). Sargassum banyak mengandung polisakarida alginat yang dimanfaatkan untuk industri makanan-minuman, kosmetik, dan farmasi. Polisakarida lainnya adalah selulosa (bagian dari dinding sel), mannitol (sebagai karbohidrat tersimpan) dan fucoidan (Kloareg et al., 1986). Selulosa pada Sargassum berkisar antara 23,97-35,22\% (Kawaroe et al., 2012; Saputra et al., 2012). Selulosa yang dimanfaatkan adalah produk turunannya yaitu carboxymethyl cellulose (CMC) yang banyak dimanfaatkan sebagai bahan penstabil, pengental, dan pengemulsi (Anon., 2014). Mannitol terkandung dalam Sargassum sebanyak 1,8-5,0\% (Kalimuthu, 1969) dimanfaatkan pada makanan dan industri farmasi (Kloareg et al., 1986).

Kandungan selulosa yang tinggi pada Sargassum merupakan salah satu potensi untuk dijadikan sebagai bahan baku untuk produksi bioetanol yang dapat dimanfaatkan sebagai sumber energi terbarukan (bioenergy). Bioetanol merupakan etanol yang diproduksi dari lignoselulosa (jagung, singkong, sorgum, kentang, gandum, tebu, dan bit) atau limbah biomassa (tongkol jagung, limbah jerami, dan limbah sayuran lainnya) atau rumput laut (Anon., 2008).

Menurut Adams et al. (2009), dengan menggunakan enzim yang tepat, selulosa, mannitol, dan laminaran dapat dihidrolisis dan dikonversi menjadi glukosa dan fruktosa setelah itu dengan menggunakan khamir dapat diproduksi menjadi bioetanol. Namun karena kompleknya komposisi dari monosakarida saat hidrolisis dan fermentasi mengakibatkan ketidakkonsistenan pada tahapan produksi bioetanol (Hyeon et al., 2011). Horn et al. (2000) melakukan penelitian produksi bioetanol dengan bahan baku mannitol dari hasil ekstraksi rumput laut coklat Laminaria hyperborea dengan menggunakan khamir Pichia angophorae. Penelitian tersebut menghasilkan etanol sebanyak $40 \%$ (b/b). P. angophorae lebih berpotensi digunakan dalam produksi bioetanol dari rumput laut coklat dibandingkan dengan Saccharomyces dikarenakan saat memfermentasi gula alkohol (mannitol) Saccharomyces membutuhkan pasokan oksigen agar tidak terjadi kekurangan enzim transhydrogenase pada saat oksidasi glukosa (lack transhydrogenase) (Quain \& Boulton, 1987). Penelitian lain yang dilakukan oleh Borines et al. (2013) yaitu produksi bioetanol dari Sargassum spp menggunakan selulase dari $T$. reeseii ATCC 26921, dan P. angophorae serta selobiase dari Aspergillus niger Novozyme 188.

Berdasarkan penelitian di atas dan melihat kenyataan kadar selulosa yang tinggi dan mannitol yang dikandungnya, Sargassum berpotensi untuk dimanfaatkan sebagai bahan baku produksi bioetanol. Kondisi optimum untuk memproduksi bioetanol dengan variasi penggunaan $T$. viride dan $P$. angophorae belum diketahui maka dilakukan penelitian ini dengan tujuan untuk mendapatkan kondisi optimum produksi bioetanol dari rumput laut coklat Sargassum duplicatum dengan menggunakan $T$. viride dan $P$. angophorae sehingga dapat diperoleh rendemen etanol yang tinggi. Tahapan produksinya meliputi hidrolisis enzimatis dan fermentasi yang kemudian diikuti dengan distilasi.

\section{BAHAN DAN METODE}

\section{Bahan}

Bahan yang digunakan adalah rumput laut coklat Sargassum duplicatum yang dipanen dari perairan di daerah Binuangeun, Propinsi Banten. S. duplicatum dibawa ke laboratorium dalam kondisi segar menggunakan cool box. Bahan lain yang digunakan adalah kapang Trichoderma viride, khamir Pichia angophorae CBS 5830, media Andreoti, pepton, tween 80, media PDA (potato dextrose agar), media GPYA (glucose peptone yeast extract agar), $\mathrm{HCl}, \mathrm{NaOH}$, dan buffer sitrat. Sedangkan bahan kimia untuk analisa adalah $\mathrm{H}_{2} \mathrm{SO}_{4}, \mathrm{NaOH}, \mathrm{HCl}$, heksan, etanol, $\mathrm{HNO}_{3}$, $\mathrm{Na}_{2} \mathrm{SO}_{3}, \mathrm{NaClO}_{2}, \mathrm{CH}_{3} \mathrm{COOH}$, glukosa standar, mannitol standar, Iarutan fenol, asam 3,5dinitrosalisilat (DNS), Na-metabisulfit, dan Iarutan buffer $\mathrm{pH}(4,7$, dan 11).

Alat-alat yang digunakan meliputi: hammer mill dengan ukuran saringan 60 mesh, stainless steel batch bioreaktor dengan double jacket hasil rakitan Balai Besar Penelitian dan Pengembangan Pengolahan Produk dan Boteknologi Kelautan dan Perikanan (BBP4BKP) kapasitas 5 liter, pH meter, $\mathrm{CO}_{2}$ detector, dissolved oxygen (DO) meter, dan peralatan distilasi. Sedangkan alat-alat analisa meliputi: Spektrometer UVIVIS (Perkin Elmer lamda 25), Breeze 2 High Performance Liquid Chromatography (HPLC) Waters, dan Gas Chromatography (GC) (Shimadzu QP2010).

\section{Metode}

Tahapan penelitian produksi bioetanol dari $S$. duplicatum meliputi: (1) pembuatan tepung $S$. duplicatum dan karakterisasi, (2) hidrolisis enzimatis, 
dan (3) fermentasi. Setelah itu dilakukan produksi bioetanol secara keseluruhan berdasarkan waktu optimum hidrolisis enzimatis dan fermentasi. Etanol kasar yang dihasilkan kemudian didistilasi untuk mendapatkan etanol murni. Setiap tahap proses dilakukan dengan dua kali ulangan. Rincian setiap tahapan tersebut dapat dilihat pada Gambar 1.

\section{Pembuatan dan karakterisasi tepung S. duplicatum}

Untuk mengurangi kristalisasi selulosa (Resita, 2006) yang dapat menurunkan kekuatan mekaniknya (Widyaningsih \& Diastuti, 2008) dan memperkecil ukuran, S. duplicatum segar yang telah dibawa ke laboratorium kemudian dibersihkan, dikeringkan, dan dihaluskan menggunakan hammer mill hingga ukuran 60 mesh. Tepung S. duplicatum diamati karakteristiknya yang meliputi kadar air (AOAC, 2005), selulosa dengan menggunakan metode TAPPI: T17 wd-70 (Irawati, 2006) yang dilakukan di Laboratorium Kimia Hasil Hutan-THH, IPB, dan penentuan kadar mannitol menggunakan HPLC yang dilakukan di
Laboratorium Terpadu, IPB dengan kondisi operasional HPLC sebagai berikut:

$\begin{array}{ll}\text { Fase gerak } & \text { : air bebas ion } \\ \text { Laju alir } & : 0,5 \mathrm{ml} / \text { menit } \\ \text { Suhu kolom } & : 80^{\circ} \mathrm{C} \\ \text { Kolom } & : \text { varian Metacarb Ca plus } \\ \text { Detector } & \text { : Refractive Index Detector (RID) } \\ \text { Pengekstrak } & \text { : air }\end{array}$

\section{Hidrolisis enzimatis}

Hidrolisis enzimatis dimaksudkan untuk mengubah selulosa menjadi gula pereduksi dengan bantuan $T$. viride sebagai penghasil selulase. Dalam tahap ini akan ditentukan waktu optimum hidrolisis (1-9 hari) untuk menghasilkan gula pereduksi total tertinggi. Dalam proses ini, T. viride dikultivasi pada media PDA miring kemudian kapang dipanen untuk digunakan dalam hidrolisis. Kultivasi T. viride dilakukan pada media PDA miring dan suhu $25-28^{\circ} \mathrm{C}$ selama tujuh hari (Arnata, 2009). Setelah hari ke tujuh, kapang dipanen dan disuspensikan dalam $10 \mathrm{ml}$ akuades steril untuk selanjutnya digunakan dalam hidrolisis.

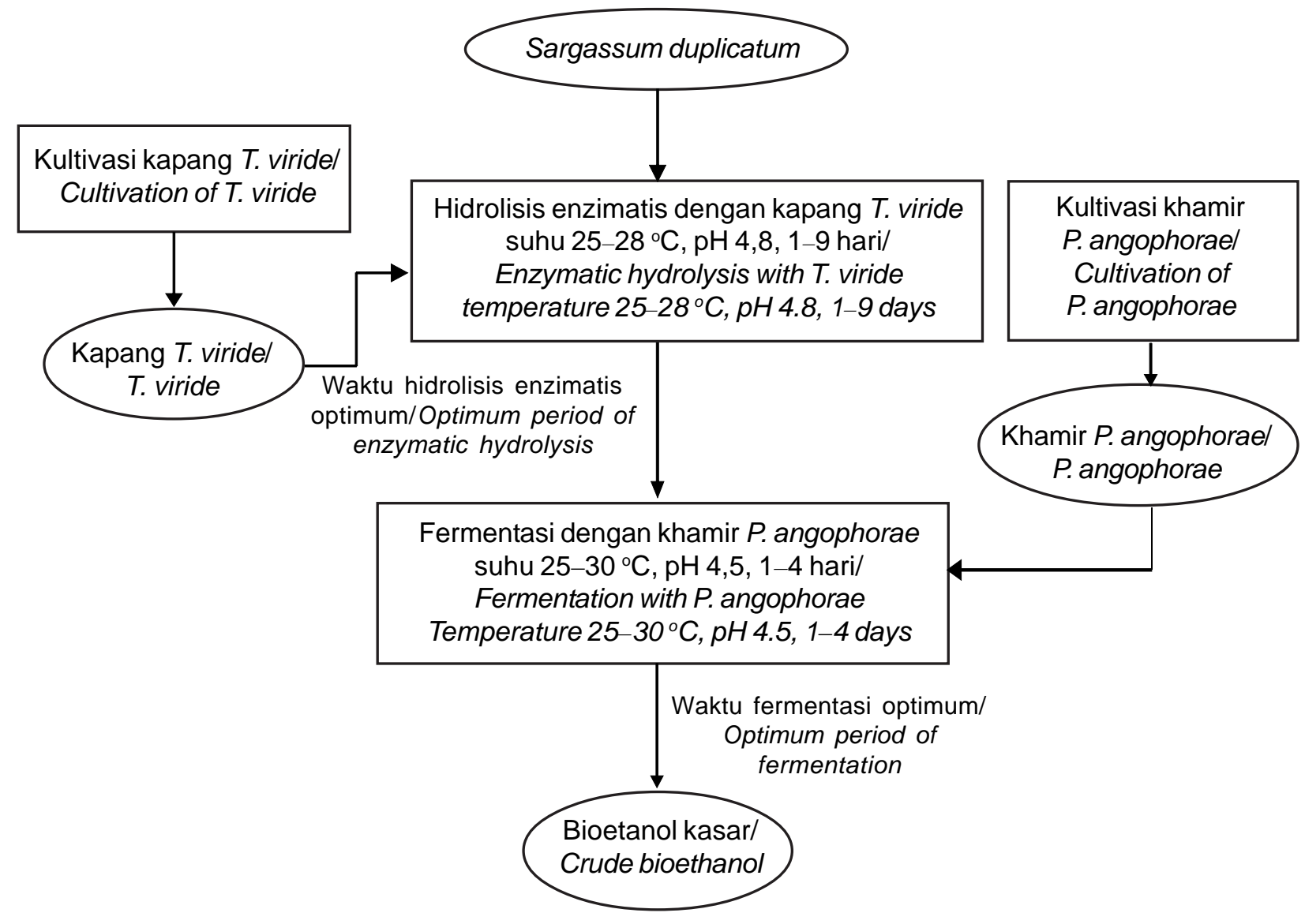

Gambar 1. Produksi bioetanol dari S. duplicatum (Sari et al., 2013).

Figure 1. Bioethanol production from S. duplicatum (Sari et al., 2013). 
Substrat untuk hidrolisis enzimatis (tepung $S$. duplicatum) sebanyak $500 \mathrm{~g}$ dimasukkan ke dalam bioreaktor kemudian ditambahkan akuades sambil diaduk sampai menjadi bubur (dikuantifikasi jumlah akuades yang diperlukan). Ke dalam substrat ditambahkan media Andreoti (Subekti, 2006), pepton sebanyak 2\%, dan tween 80 0,1\% (Arnata, 2009) dengan dilakukan pengadukan. Kemudian $\mathrm{pH}$ diatur menjadi 4,8 (Arnata, 2009) dengan penambahan $\mathrm{HCl}$ $3 \mathrm{M}$ atau $\mathrm{NaOH} 3 \mathrm{M}$. Penggunaan asam dan basa normalitas tinggi ini dimaksudkan agar saat mengatur $\mathrm{pH}$ tidak terjadi penambahan volume substrat yang banyak. Kemudian $\mathrm{pH}$ dijaga dengan penambahan buffer sitrat 0,2 M. Selanjutnya substrat disterilisasi dengan pemanasan pada $100{ }^{\circ} \mathrm{C}$ selama 30 menit (Hogg, 2005). Setelah itu substrat didinginkan hingga 25-28 ${ }^{\circ} \mathrm{C}$. Selama hidrolisis berlangsung tidak dilakukan pengadukan (Jenie, 1990) untuk menghindari masuknya oksigen karena hidrolisis selulosa menjadi gula berjalan dalam kondisi anaerobik.

Substrat yang telah disiapkan kemudian ditambah suspensi $T$. viride sebanyak $10 \%(\mathrm{v} / \mathrm{v})$ dari $100 \mathrm{~mL}$ substrat. Hidrolisis dilakukan selama sembilan hari pada suhu $25-28{ }^{\circ} \mathrm{C}$ (Gunam et al., 2011). Pengambilan sampel dilakukan setiap hari selama proses berlangsung. Analisa yang dilakukan adalah: aktivitas enzim CMCase dengan metode Mandels et al. (1976), kandungan gula total dengan metode Phenol Sulfat (Dubois et al., 1956), dan gula pereduksi total dengan metode DNS (Miller, 1959) serta dilakukan pengukuran suhu dan $\mathrm{pH}$ selama hidrolisis.

\section{Fermentasi}

Fermentasi dimaksudkan untuk mengubah gula pereduksi total hasil hidrolisis enzimatis dan fruktosa menjadi etanol dengan bantuan $P$. angophorae. Dalam tahap ini akan ditentukan waktu optimum selama 1-4 hari untuk menghasilkan kadar etanol kasar tertinggi.

Kapang $P$. angophorae dikultivasi pada media glucose, peptone, yeast extract dan bacto agar (GPYA) pada suhu $25^{\circ} \mathrm{C}$ selama 5 hari (Sari, 2010). Komposisi media GPYA per $1000 \mathrm{~mL}$ akuades adalah glukosa sebanyak $40 \mathrm{~g}$, bacto peptone $5 \mathrm{~g}$, yeast extract $5 \mathrm{~g}$ dan bacto agar $15 \mathrm{~g}$ (Carvajal et al., 2006). Setelah hari ke lima, $P$. angophorae dipanen dan disuspensikan dalam $10 \mathrm{ml}$ akuades steril untuk digunakan dalam fermentasi.

Fermentasi dengan menggunakan substrat hasil hidrolisis enzimatis dilakukan berdasarkan waktu optimum hidrolisis hasil pecobaan sebelumnya. Pada akhir hidrolisis enzimatis dilakukan inaktivasi $T$. viride dengan memanaskan substrat pada suhu $65{ }^{\circ} \mathrm{C}$ selama 30 menit (Prihatini, 2008). Selanjutnya substrat didinginkan menjadi suhu $25-30{ }^{\circ} \mathrm{C}, \mathrm{pH}$ substrat diatur menjadi 4,5 dengan penambahan $\mathrm{HCl}$ $3 \mathrm{M}$ atau $\mathrm{NaOH} 3 \mathrm{M}$ (Horn, 2000) dan dijaga dengan penambahan buffer sitrat $0,2 \mathrm{M}$. Substrat dipanaskan pada suhu $100{ }^{\circ} \mathrm{C}$ selama 30 menit (Hogg, 2005) kemudian didinginkan menjadi suhu $25-30^{\circ} \mathrm{C}$.

Substrat yang telah disiapkan kemudian ditambah suspensi $P$. angophorae sebanyak $10 \%(\mathrm{v} / \mathrm{v})$ untuk tiap $100 \mathrm{ml}$ media. Fermentasi ini berlangsung selama 4 hari pada suhu $25-30{ }^{\circ} \mathrm{C}$ (Horn, 2000). Selama proses berlangsung dilakukan pengadukan secara kontinyu dengan kecepatan 12 rpm (Irawati, 2006; Subekti, 2006; dan Arnata, 2009) serta dilakukan pengambilan sampel setiap hari untuk memantau kadar etanol kasar. Selama proses juga dilakukan pengukuran suhu, $\mathrm{pH}$, laju pembentukan $\mathrm{CO}_{2}$, dan oksigen terlarut (DO) (Horn, 2000).

\section{Produksi bioetanol}

Produksi bioetanol dilakukan berdasarkan waktu optimum hidrolisis enzimatis dan fermentasi. Etanol yang dihasilkan didistilasi untuk menghasilkan etanol murni.

Substrat hasil fermentasi dipisahkan antara padatan dan cairan (filtrat). Filtrat yang dihasilkan selanjutnya dimurnikan dengan distilasi. Distilasi dilakukan dengan memasukkan filtrat ke distilator dan dipanaskan pada suhu $80^{\circ} \mathrm{C}$. Air sebagai media pendingin bersuhu $10^{\circ} \mathrm{C}$ dialirkan pada kondensor. Distilasi ini dilakukan selama 2 jam (Irawati, 2006; Subekti, 2006). Distilat yang dihasilkan kemudian dianalisa kadar etanolnya dengan menggunakan GC di Laboratorium Forensik-Mabes Polri, Jakarta.

\section{HASIL DAN PEMBAHASAN}

\section{Karakteristik Tepung S. duplicatum}

Karakteristik tepung $S$. duplicatum diamati berdasarkan kadar air, selulosa, dan mannitol. Rumput laut $S$. duplicatum yang digunakan memiliki kadar air $9,41 \pm 0,18 \%$, selulosa $15,80 \pm 0,79 \%$, dan mannitol 0,71\%.

Dari hasil tersebut tampak bahwa kadar air tepung S. duplicatum tidak berbeda dengan dengan kadar air bahan baku yang digunakan untuk produksi bioetanol yang digunakan peneliti lain yaitu berkisar antara 7,04-11,16\% (Subekti, 2006; Shofiyanto, 2008; Borines et al., 2013). Kadar air tersebut dijaga agar tidak tinggi (maksimal 14-15\%) karena menurut Loebis (2008) kadar air bahan baku akan berpengaruh pada pertumbuhan kapang, aktivitas enzim, penurunan porositas, dan laju difusi oksigen. Kadar selulosa $S$. duplicatum tidak berbeda dengan kadar selulosa 
bahan baku yang digunakan untuk produksi bioetanol dalam penelitian-penelitian sebelumnya yaitu 3,525,50\% (Horn, 2000; Harvey, 2008; Siddhanta et al., 2011; Santi et al., 2012; Borines et al., 2013). Kadar mannitol S. duplicatum lebih kecil dibandingkan dengan kadar mannito/ bahan baku yang digunakan untuk produksi bioetanol pada penelitian sebelumnya yaitu 5,04\% (Borines et al., 2013).

Kadar selulosa dan mannitol ini dapat mempengaruhi potensi bahan baku yang digunakan untuk memproduksi bioetanol. Selulosa yang terdapat dalam S. duplicatum berperan sebagai penginduksi enzim CMCase (endoglukanase) yang menjadi sumber karbon untuk pertumbuhan kapang $T$. viride sedangkan mannitol menjadi sumber karbon untuk pertumbuhan khamir $P$. angophorae sehingga rumput laut $S$. duplicatum berpotensi sebagai bahan baku untuk produksi bioetanol.

\section{Hidrolisis Enzimatis}

\section{Suhu dan $\mathrm{pH}$ substrat}

Suhu selama hidrolisis enzimatis berkisar antara 27-31 ${ }^{\circ} \mathrm{C}$. Suhu substrat telah sesuai untuk mendukung pertumbuhan $T$. viride dan produksi enzim selulase. Suhu optimal pertumbuhan $T$. viride sekitar $32-35^{\circ} \mathrm{C}$ dan untuk produksi enzim sekitar $25-28^{\circ} \mathrm{C}$ (Waluyo, 2004). Namun suhu optimal untuk produksi enzim selulase secara maksimal juga tergantung pada strain Trichoderma sp. yang digunakan (Gautam et al., 2010).

Perubahan $\mathrm{pH}$ selama hidrolisis enzimatis berkisar antara 5,38-5,96. Nilai $\mathrm{pH}$ substrat telah sesuai dengan aktifitas enzim selulase untuk menguraikan selulosa menjadi glukosa sebagaimana hasil penelitian lain (Susilawati et al., 2002; Ratnakomala, 2010; Nenci, 2012). Menurut hasil penelitian Ratnakomala (2010) pH optimum enzim selulase Trichoderma sp strain 1008-T004 adalah pada pH 5 dan strain 1008-T063 pada pH 6. Penelitian lainnya yaitu Nenci (2012) memperoleh aktivitas enzim selulase dari T. viride strain T051 optimum pada $\mathrm{pH} 5$ sedangkan Susilawati et al. (2002) mendapatkan pH optimum untuk enzim selulase pada kisaran $\mathrm{pH}$ 4,56,5 .

\section{Aktivitas enzim selulase (CMCase)}

Hasil analisis aktivitas enzim selulase (CMCase) (Gambar 2) menunjukkan bahwa aktivitas CMCase berada pada kisaran $0,42-3,48 \mathrm{IU} / \mathrm{ml}$ substrat. Pada hari pertama sampai hari ke empat aktivitas enzim mengalami kenaikan hingga mencapai nilai maksimum. Hal ini diduga karena telah terjadi kesesuaian substrat dan kondisi optimum yang dapat mendukung kapang memproduksi enzim endoßglukanase untuk mendegradasi fraksi selulosa dalam substrat menjadi glukosa dan selooligosakarida. Selanjutnya pada hari ke lima sampai akhir pengamatan aktivitas CMCase cenderung menurun. Hal ini diduga karena $\mathrm{pH}$ substrat terus mengalami kenaikan menjadi 5,96. Menurut Molla et al. (2004) Trichoderma spp. dapat tumbuh dan memetabolisme substrat pada kisaran $\mathrm{pH}$ 3-5.

Aktivitas CMCase yang dihasilkan dari penelitian ini lebih rendah dibandingkan hasil penelitian Zhou et al. (2008); Arnata (2009); dan Neethu et al. (2012). Hal ini diduga karena perbedaan jenis substrat yang digunakan saat hidrolisis enzimatis. Menurut Bakare et al. (2006) aktivitas enzim selulase sangat dipengaruhi oleh jenis dan konsentrasi substrat untuk pencapaian aktivitas tertinggi sampai fase jenuh.

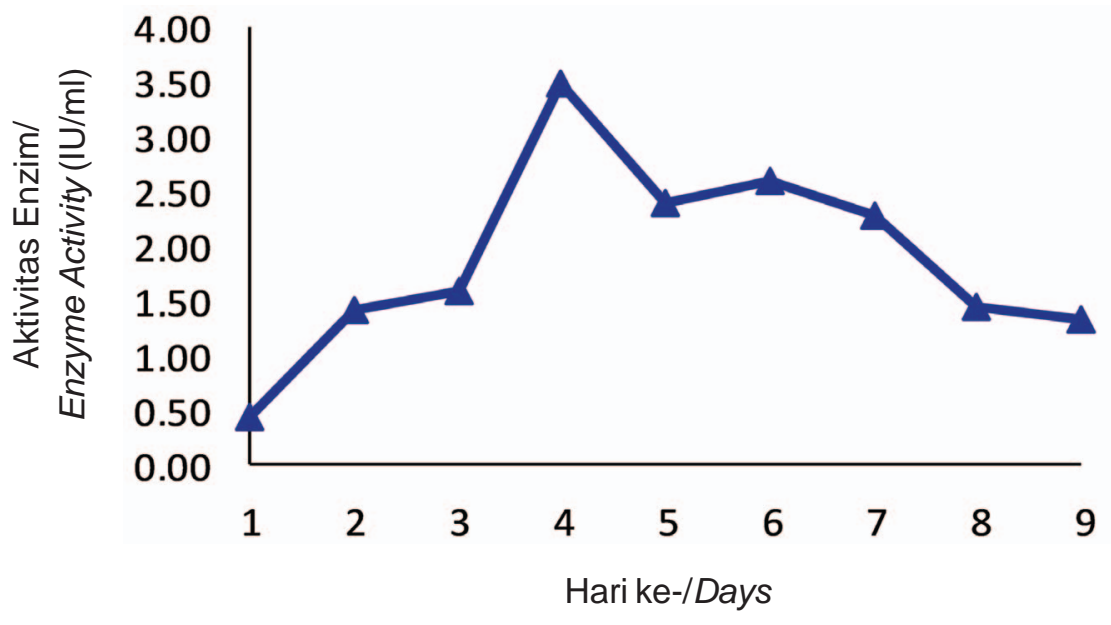

Gambar 2. Aktivitas CMCase dari T. viride.

Figure 2. CMCase activity of $T$. viride. 
Penelitian Neethu et al. (2012) menggunakan bahan baku Basal Mineral Salt Medium (BSM) yang ditambahkan CMC 1,25\% menghasilkan aktivitas selulase maksimum $173 \mathrm{IU} / \mathrm{ml}$ pada hari ke enam dengan kondisi optimum pada suhu $28^{\circ} \mathrm{C}$ dan $\mathrm{pH}$ 4. Penelitian Arnata (2009) dengan bahan baku ubi kayu menghasilkan aktivitas CMCase maksimum $5,05 \mathrm{IU} / \mathrm{ml}$ substrat pada hari ketujuh dengan kondisi optimum pada suhu $25-28^{\circ} \mathrm{C}$ dan $\mathrm{pH} 3,28$. Sedangkan Zhou et al. (2008) menggunakan Avicel $1 \%$ menghasilkan aktivitas CMCase maksimum pada hari ke empat sebesar 13,83 IU/ml substrat.

Formulasi susbtrat untuk pertumbuhan kapang dan produksi enzim merupakan faktor penting yang mempengaruhi desain penelitian yang akan dilakukan. Dibandingkan dengan kondisi penelitian yang sudah disebutkan sebelumnya penggunaan substrat $S$. duplicatum yang dihidrolisis $T$. viride menghasilkan aktivitas CMCase maksimal hari ke empat pada suhu $28^{\circ} \mathrm{C}$ dan $\mathrm{pH} 5,77$.

\section{Gula total}

Gula total yang dihasilkan selama hidrolisis enzimatis dapat dilihat pada Gambar 3 dengan kisaran $1,98-3,73 \mathrm{~g} / \mathrm{L}$. Selama proses berlangsung gula total memiliki kecenderungan meningkat sampai akhir pengamatan. Dari hari pertama sampai hari ke dua gula total mengalami kenaikan namun di hari ke tiga gula total mengalami penurunan yang signifikan. Selanjutnya dari hari ke empat sampai akhir pengamatan gula total memiliki kecenderungan meningkat. Kecenderungan meningkatnya gula total selama hidrolisis enzimatis ini diduga karena kondisi substrat sudah optimum untuk mendukung kapang memproduksi enzim endo-ß-glukanase yang mendegradasi fraksi selulosa dalam media menjadi glukosa dan selo-oligosakarida. Konsentrasi gula total dalam substrat dapat mempengaruhi pertumbuhan kapang. Semakin tinggi konsentrasi gula total dalam substrat maka pertumbuhan kapang juga semakin tinggi (Pramanik, 2003).

\section{Gula pereduksi total}

Gula pereduksi total yang dihasilkan selama hidrolisis enzimatis dapat dilihat pada Gambar 4 dengan kisaran 2,34-4,45 mg/L. Pada awal hidrolisis gula pereduksi total cenderung mengalami kenaikan. Kemudian pada hari ke empat sampai ke tujuh gula pereduksi total mengalami penurunan. Selanjutnya pada hari ke delapan gula pereduksi total meningkat dan menurun kembali di akhir pengamatan. Kecenderungan meningkatnya gula pereduksi total selama hidrolisis enzimatis ini diduga karena pada awal hidrolisis enzimatis terjadi aktivitas selulase secara sinergis antara endoglukanase (CMCase), selobiohidrolase, dan beta-glukosidase. Endoglukonase menghidrolisis ikatan 1,4 secara acak dan bekerja pada bagian amorf dari serat selulosa. Selanjutnya selobiohidrolase menghidrolisis ujung rantai selulosa menghasilkan selobiosa, di mana selobiosa ini dihidrolisis oleh $\beta$-glukosidase menjadi glukosa. Hal ini ditunjukkan dengan pencapaian gula pereduksi total tertinggi pada hari ke tiga dan ke empat yaitu 4,45 dan 4,26 mg/L. Da Silva et al. (2005) menyatakan bahwa sistem pemecahan selulosa menjadi glukosa terdiri dari tiga jenis selulase yaitu endo-beta-1,4-glukanase, ekso-beta-1,4-glukanase, dan beta-glukosidase. Di akhir hidrolisis enzimatis terjadi penurunan gula pereduksi total yang diduga terjadi karena tingginya gula pereduksi total yang terbentuk pada substrat telah menghambat aktivitas

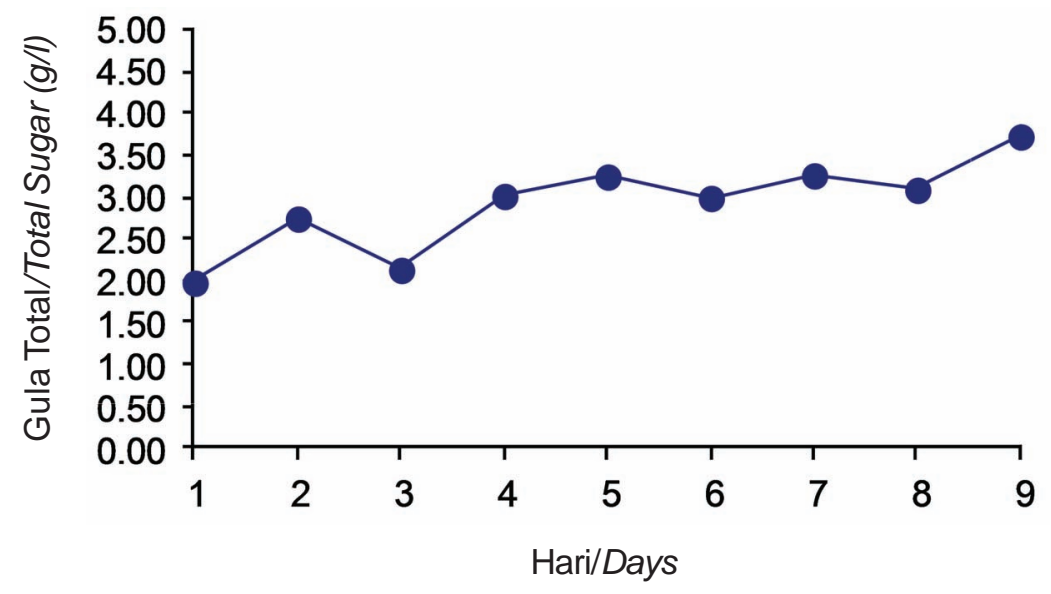

Gambar 3. Gula total yang dihasilkan pada hidrolisis enzimatis Figure 3. Total sugar resulted from enzymatic hydrolysis 


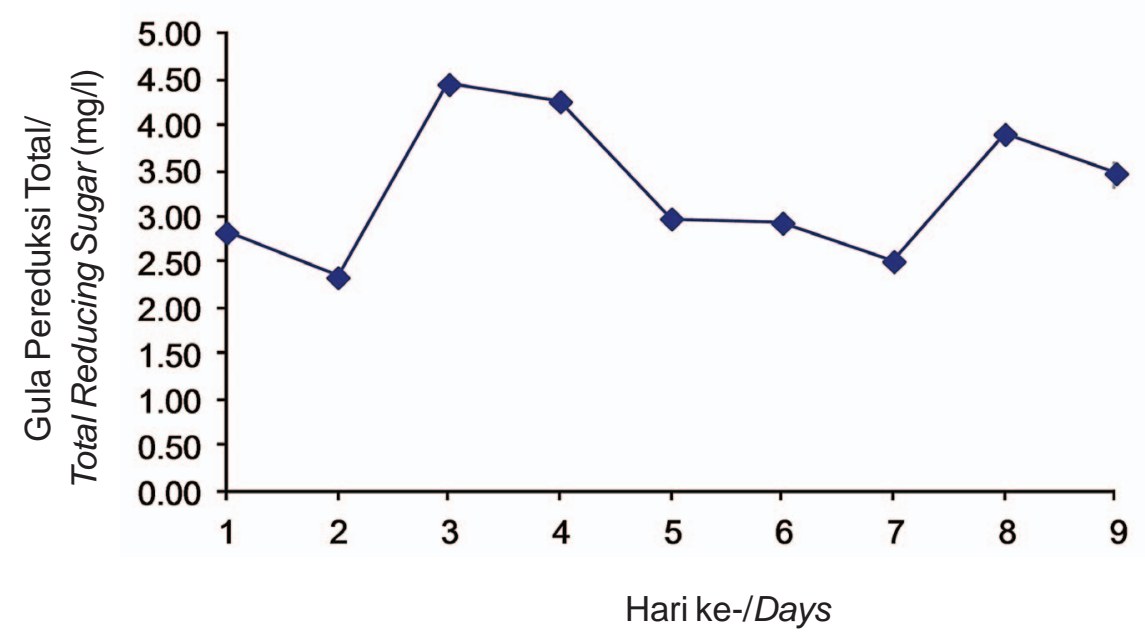

Gambar 4. Gula pereduksi total yang dihasilkan dari hidrolisis enzimatis.

Figure 4. Total reducing sugar resulted from enzymatic hydrolysis.

enzim selulase untuk memproduksi gula pereduksi (feedback inhibition).

Hasil gula pereduksi total yang diperoleh dari penelitian ini lebih tinggi dibandingkan hasil penelitian Ashriyani (2009). Penelitian tersebut menggunakan bahan baku rumput laut Eucheuma dan Glacilaria untuk produksi bioetanol. Gula pereduksi yang dihasilkan dari hidrolisis enzimatis Eucheuma menggunakan $T$. viride selama 48 jam sebesar 0,09 $\mathrm{mg} / \mathrm{ml}$ dan Gracilaria $0,09 \mathrm{mg} / \mathrm{ml}$. Perbedaan gula pereduksi yang dihasilkan diduga karena perbedaan konsentrasi bahan baku yang digunakan dan waktu hidrolisis enzimatis. Penelitian ini menggunakan S. duplicatum dengan konsentrasi $0,17 \mathrm{~g} / \mathrm{ml}$ sedangkan Ashriyani (2009) menggunakan tepung Eucheuma konsentrasi 0,08 g/ml dan tepung Gracilaria 0,05 g/ $\mathrm{ml}$. Faktor lain yang juga berpengaruh adalah kadar selulosa pada bahan baku. Kadar selulosa pada $S$. duplicatum yang menjadi bahan baku pada penelitian ini sebesar $15,80 \%$ berat kering. Sedangkan kadar selulosa pada Eucheuma dan Gracilaria berturut-turut 19,7 dan 7,1\% berat kering (Kim et al., 2007). Menurut Saparianti et al. (2012) semakin banyak substrat selulosa yang bisa dihidrolisis oleh selulase menjadi monomernya maka semakin tinggi kadar glukosanya.

Dari hasil penelitian di atas, waktu optimum hidrolisis enzimatis S.duplicatum menggunakan kapang $T$. viride adalah selama empat hari dengan aktivitas enzim CMCase $3,48 \mathrm{IU} / \mathrm{ml}$ pada suhu $28^{\circ} \mathrm{C}$ dan $\mathrm{pH}$ 5,77 menghasilkan gula total 3,01 $\mathrm{g} / \mathrm{L}$ dan gula pereduksi total $4,26 \mathrm{mg} / \mathrm{L}$. Faktor utama yang menentukan kondisi optimum tersebut adalah gula pereduksi total karena persentase dari gula pereduksi total dapat menentukan konsentrasi etanol (bioetanol) yang dihasilkan dari proses fermentasi selanjutnya. Namun demikian pada penelitian ini juga dipertimbangkan aktivitas selulase. Meskipun gula pereduksi total tertinggi dihasilkan pada hari ke tiga, aktivitas selulase dicapai pada hari ke empat sehingga waktu optimum adalah pada hari ke empat. Lama waktu hidrolisis enzimatis ini juga didukung oleh hasil penelitian Yanagisawa et al. (2011) yang menyatakan bahwa konsentrasi glukosa yang dihasilkan dari rumput laut coklat chigaiso (Alaria crassifolia Kjellman) menggunakan enzim meicelase CEPB-5394 dari $T$. viride adalah $67,2 \mathrm{~g} / \mathrm{L}$ pada hidrolisis hari ke empat.

Setelah hidrolisis enzimatis selesai kemudian dilanjutkan dengan fermentasi.

\section{Fermentasi}

\section{Suhu dan $\mathrm{pH}$ substrat}

Suhu selama fermentasi berkisar antara $27-31^{\circ} \mathrm{C}$. Suhu substrat ini sudah memungkinkan $P$. angophorae tumbuh dengan baik. Suhu untuk pertumbuhan $P$. angophorae adalah $25-35^{\circ} \mathrm{C}$ (Anon., 2009).

Perubahan $\mathrm{pH}$ yang terukur pada fermentasi selama empat hari berkisar antara 4,17-4,42. pH substrat sudang mendukung $P$. angophorae untuk dapat memfermentasi S. duplicatum menjadi etanol. Horn (2000) memproduksi bioetanol dari ekstrak rumput laut coklat $L$. hyperborea menggunakan $P$. angophorae dengan kisaran $\mathrm{pH}$ antara 4-5,5.

\section{Tingkat pertumbuhan $P$. angophorae}

Tingkat pertumbuhan $P$. angophorae dinyatakan dengan nilai optical density yang diukur pada panjang 
gelombang $600 \mathrm{~nm}$ (OD600) yang hasilnya dapat dilihat pada Gambar 5. Hasilnya, OD600 P. angophorae ada pada kisaran $0,36-0,75$. Tingkat pertumbuhan $P$. angophorae ini rendah. Nilai ideal OD600 adalah berkisar antara 1,5-2,5 (Anon., 2015). Rendahnya tingkat pertumbuhan $P$. angophorae diduga karena inhibisi oleh polyphenols atau ion alkali yang terdapat pada S. duplicatum. Faktor-faktor yang menyebabkan terjadinya inhibisi pada fermentasi makroalga oleh $P$. angophorae adalah polyphenols, adanya ion alkali pada makroalga, inhibisi nutrisi karena defisiensi atau inhibisi produk seperti meningkatnya konsentrasi etanol (Adams et al., 2011).

Selama fermentasi tingkat pertumbuhan $P$. angophorae memiliki kecenderungan meningkat sampai hari ke empat. Hal ini diduga karena $P$. angophorae memanfaatkan glukosa yang ada pada substrat sebagai nutrisi untuk pertumbuhan karena glukosa merupakan gula sederhana yang mampu dikonsumsi tanpa harus mengalami proses pemecahan terlebih dahulu sebagaimana bila substrat berupa polisakalida atau oligosakarida (Tanti et al., 2011).

\section{Oksigen terlarut}

Oksigen terlarut (dissolved oxygen; DO) selama fermentasi dapat dilihat pada Gambar 6, yaitu berkisar antara $10,3-18,1 \%$. Dari gambar tersebut dapat dilihat oksigen terlarut cenderung menurun bersamaan dengan waktu fermentasi. Pada awal fermentasi, oksigen terlarut dalam substrat masih tinggi kemudian cenderung turun sampai fermentasi selesai. Menurunnya oksigen terlarut diduga terjadi karena khamir memasuki fase pertumbuhan awal sampai logaritmik sehingga diperlukan oksigen lebih banyak untuk mendukung pertumbuhannya. Oksigen terlarut dalam substrat fermentasi ini sudah berada pada batasan tidak lebih dari $20 \%$. Karena apabila oksigen terlarut lebih dari $20 \%$ maka dapat meningkatkan produksi asam organik dan mengurangi rendemen bioetanol (Horn, 2000).

Menurut Wirahadikusumah (1985) menurunnya oksigen terlarut dalam substrat selama fermentasi berlangsung menyebabkan respirasi khamir terhenti dan proses pengangkutan elektron yang dirangkaikan dengan fosforilasi bersifat oksidasi melalui rantai pernafasan yang menggunakan molekul oksigen sebagai penerima elektron terakhir tidak berjalan. Akibatnya jalan metabolisme lingkar asam trikarboksilat (daur Krebs) akan terhenti pula sehingga piruvat tidak lagi masuk ke daur Krebs melainkan dialihkan pemakaiannya yaitu diubah menjadi etanol.

Selama fermentasi berlangsung dilakukan pengadukan (agitasi). Pengadukan bertujuan untuk memperlancar difusi oksigen dalam media sehingga mendukung pertumbuhan sel khamir secara aerobik dan konsentrasi substrat lebih merata. Oksigen dalam substrat diperlukan oleh $P$. angophorae untuk mengubah NADH (Nicotinamide Adenine Dinucleotide, $\mathrm{NAD}^{+}$) menjadi NADPH (Nicotinamide Adenine Dinucleotide Phosphate, $\mathrm{NADP}^{+}$) yang akan mengoksidasi mannitol menjadi fruktosa $\left(\mathrm{C}_{6} \mathrm{H}_{12} \mathrm{O}_{6}\right)$ dan selanjutnya dikonversi menjadi bioetanol (Horn, 2000).

\section{Konsentrasi $\mathrm{CO}_{2}$}

Konsentrasi $\mathrm{CO}_{2}$ yang dihasilkan selama proses fermentasi dapat dilihat pada Gambar 7 yaitu berkisar antara 320,72-1052,76 ppm. Dari Gambar 7 tersebut dapat terlihat konsentrasi $\mathrm{CO}_{2}$ cenderung berfluktuasi sampai hari ke empat. Hal ini diduga karena selama fermentasi berlangsung $P$. angophorae telah memetabolisme glukosa membentuk asam piruvat melalui tahapan reaksi pada jalur Embden-Meyerhof-

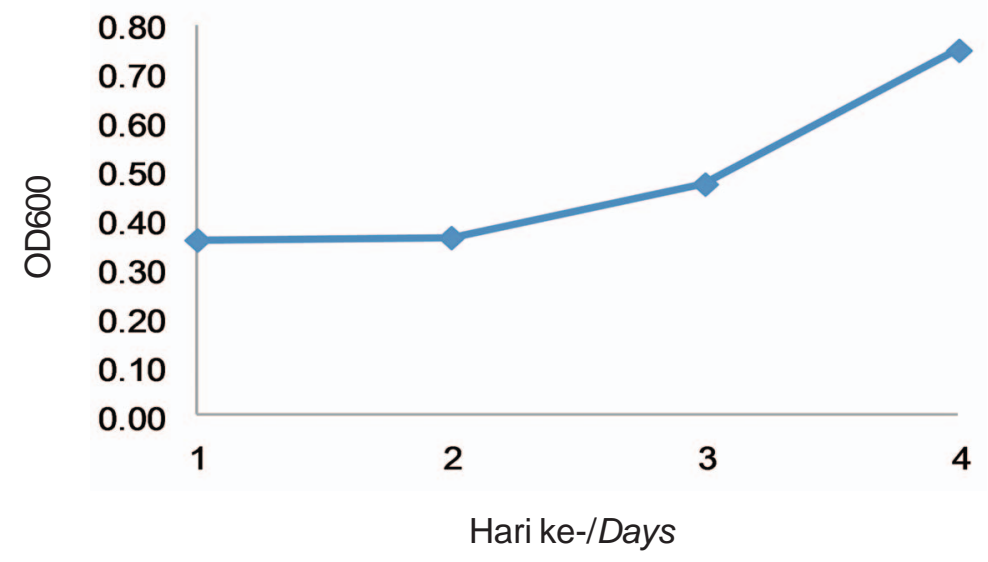

Gambar 5. Tingkat pertumbuhan P. angophorae.

Figure 5. Growth rate of P. angophorae. 


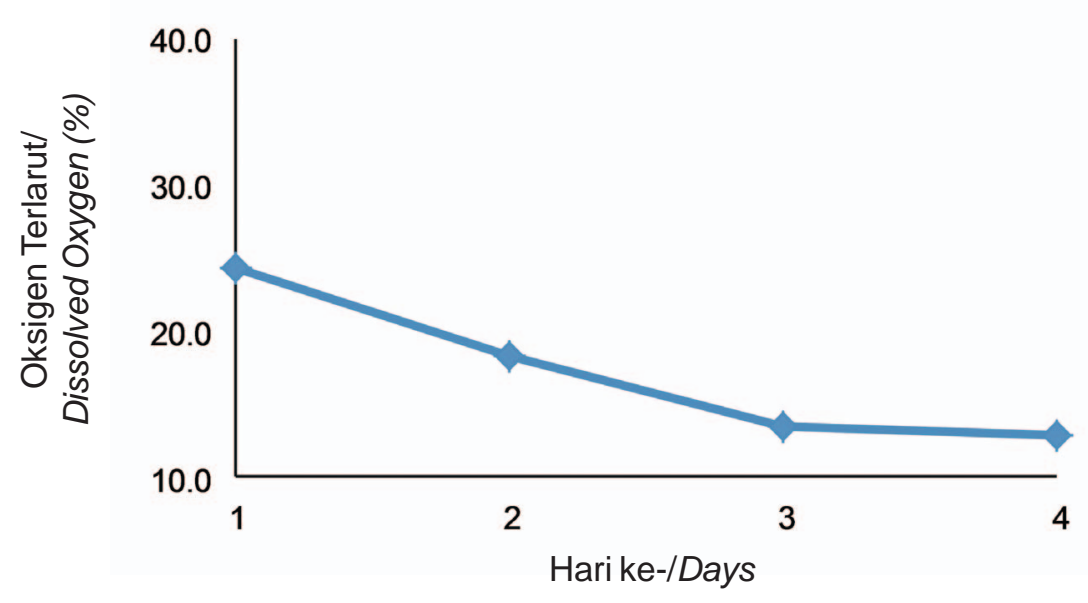

Gambar 6. Oksigen terlarut dalam substrat fermentasi.

Figure 6. Dissolved oxygen in fermentation substrate.

Parnas. Sedangkan asam piruvat yang dihasilkan akan didekarboksilasi menjadi asetaldehid yang kemudian mengalami dehidrogenasi menjadi etanol, $\mathrm{CO}_{2}$, dan energi (ATP) (Subekti, 2006).

\section{Kadar etanol kasar}

Kadar etanol kasar selama fermentasi dapat dilihat pada Gambar 8 yang berkisar antara 0,01-0,04 g/L. Dari Gambar 8 tersebut jika dilihat secara keseluruhan kadar etanol kasar cenderung fluktuatif namun tidak berbeda nyata. Pada hari pertama fermentasi berlangsung diduga kondisi substrat sudah mendukung $P$. angophorae untuk mengkonsumsi mannitol dengan cepat dan dengan bantuan mannitol dehidrogenase, $P$. angophorae mampu mengoksidasi mannitol menjadi fruktosa kemudian mengkonversinya menjadi etanol (Van Dijken \& Scheffers, 1986). Sedangkan di hari ke dua terjadi proses glikolisis yaitu proses perubahan satu molekul glukosa menjadi dua molekul piruvat dan dilanjutkan dengan proses dekarboksilasi piruvat menjadi asetaldehid dan $\mathrm{CO}_{2}$ dengan katalis piruvat dekarboksilase. Kondisi ini didukung dengan konsentrasi $\mathrm{CO}_{2}$ pada hari ke dua tertinggi yaitu $1052,76 \mathrm{ppm}$ dan $\mathrm{pH}$ substrat dari 4,44 menjadi 4,09 . Kemudian pada hari ke tiga terjadi kenaikan kadar etanol kembali. Hal ini diduga karena $P$. angophorae dengan kecukupan sumber karbon (fruktosa dan glukosa hasil hidrolisis enzimatis) memasuki fase logaritmik dan mereduksi asetaldehid menjadi etanol. Proses reduksi tersebut dilakukan oleh nikotinamida adenin dinukleotida ditambah ion hidrogen (NADH) dan dikatalisis dengan alkohol dehidrogenase. Menurut Voet et al. (2006) pembentukan NAD+ tersebut akan digunakan dalam proses reaksi gliseraldehida 3-fosfat dehidrogenase (GADPH) glikolisis. Kondisi demikian menyebabkan kadar etanol meningkat dan mencapai maksimum. Di akhir pengamatan, biomassa $P$. angophorae masih terus bertambah sementara sumber karbon semakin berkurang maka kadar etanol yang dihasilkan pun menurun kembali.

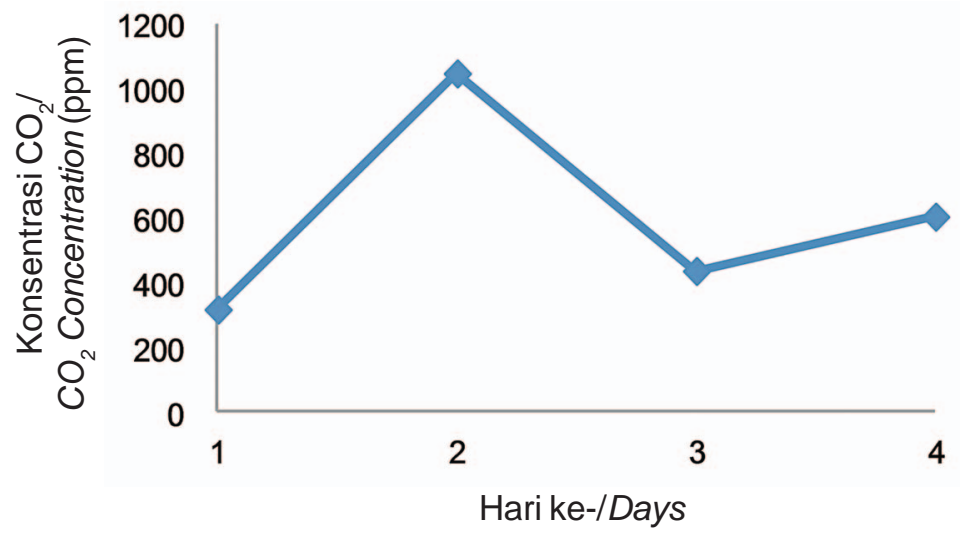

Gambar 7. Konsentrasi $\mathrm{CO}_{2}$ selama fermentasi. Figure 7. $\mathrm{CO}_{2}$ concentration during fermentation. 


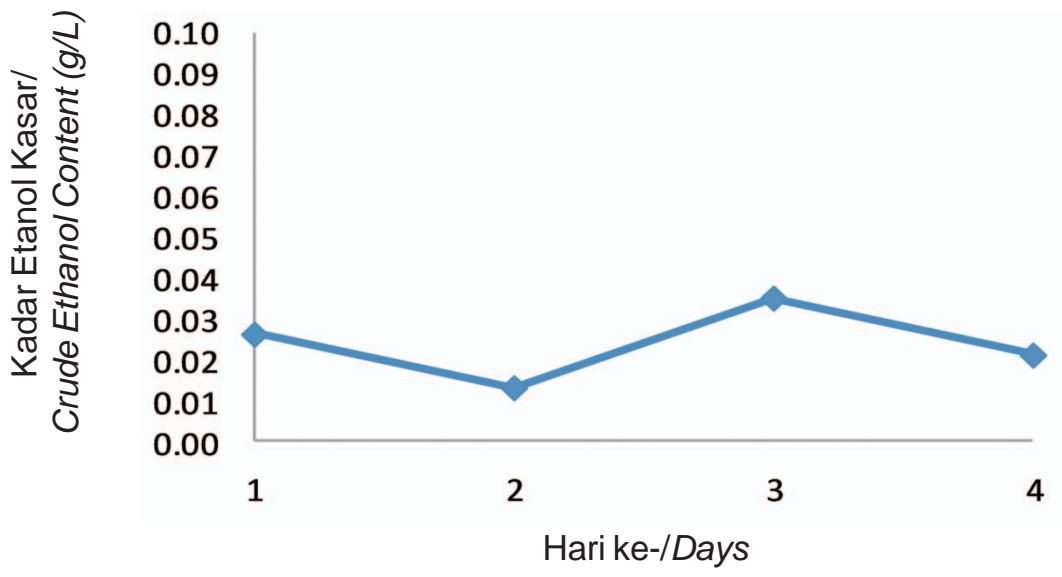

Gambar 8. Kadar etanol kasar yang dihasilkan selama fermentasi.

Figure 8. Crude ethanol content resulted during fermentation.

Kadar etanol kasar tertinggi dihasilkan pada fermentasi hari ke tiga yaitu $0,04 \mathrm{~g} / \mathrm{L}$. Kadar etanol kasar yang dihasilkan dari fermentasi ini masih lebih rendah dibandingkan dengan hasil penelitian Horn et al. (2000) yang menggunakan $P$. angophorae dalam memfermentasi ekstrak rumput laut coklat $L$. hyperborea menjadi etanol dengan rendemen $0,43 \mathrm{~g} /$ g substrat $(40 \%(b / b))$. Rendahnya kadar etanol kasar ini diduga terjadi karena pada bahan baku $S$. duplicatum masih terdapat senyawa-senyawa lain seperti alginat, fucoidan, protein, dan polyphenols yang menyebabkan kinerja $P$. angophorae menjadi tidak efektif.

Dari hasil penelitian di atas, waktu optimum fermentasi $S$. duplicatum menggunakan $P$. angophorae adalah tiga hari dengan tingkat pertumbuhan (OD 600) 0,48; oksigen terlarut $13,4 \%$, konsentrasi $\mathrm{CO}_{2} 440,33 \mathrm{ppm}$, suhu $29^{\circ} \mathrm{C}$ dan $\mathrm{pH} 4,17$ menghasilkan kadar etanol kasar 0,04 g/L. Waktu fermentasi ini didukung oleh penelitian yang dilakukan oleh Borines et al. (2013) dan Ota et al. (2013). Borines et al. (2013) menghasilkan etanol dengan konsentrasi 2,27 g/L selama tiga hari fermentasi Sargassum spp. menggunakan S. cerevisiae pada suhu $40^{\circ} \mathrm{C}$ dan $\mathrm{pH} 4,5$. Ota et al. (2013) menghasilkan etanol juga selama tiga hari fermentasi mannitol menggunakan P. angophorae CBS 5830.

Etanol kasar yang dihasilkan kemudian didistilasi sehingga kadar etanolnya meningkat menjadi 10,50 $\mathrm{g} / \mathrm{L}$. Berdasarkan kadar etanol tersebut untuk memproduksi $1 \mathrm{~L}$ bioetanol diperlukan tepung $S$. duplicatum sebanyak 2,90 ton atau 41,40 ton $S$. duplicatum segar. Dengan harga jual bioetanol Rp. 10.000,-/L maka produksi bioetanol dengan bahan baku S. duplicatum menggunakan $T$. viride dan $P$. angophorae secara ekonomi belum layak dikembangkan.

\section{KESIMPULAN}

Produksi bioetanol dari rumput laut coklat $S$. duplicatum menghasilkan kadar etanol tertinggi dengan kondisi optimum sebagai berikut: (a). Hidrolisis enzimatis menggunakan $T$. viride selama empat hari dengan aktivitas enzim CMCase 3,48 IU/ml pada suhu $28^{\circ} \mathrm{C}$ dan $\mathrm{pH} 5,77$ menghasilkan gula total $3,01 \mathrm{~g} / \mathrm{L}$ dan gula pereduksi total $4,26 \mathrm{mg} / \mathrm{L}$; (b). Fermentasi menggunakan khamir $P$. angophorae selama tiga hari dengan tingkat pertumbuhan (OD600) 0,48 pada suhu $29^{\circ} \mathrm{C}, \mathrm{pH} 4,17$, oksigen terlarut $13,4 \%$, dan konsentrasi $\mathrm{CO}_{2} 440,33 \mathrm{ppm}$ menghasilkan kadar etanol kasar 0,04 g/L. Distilasi mampu meningkatkan kadar etanol menjadi 10,50 g/L.

Keseimbangan massa pada produksi bioetanol ini adalah selulosa sebanyak $79 \mathrm{~g}$ dan mannitol $3,55 \mathrm{~g}$ menghasilkan gula pereduksi total $4,26 \mathrm{mg} / \mathrm{L}$ dan kadar etanol kasar 0,04 g/L sehingga untuk memproduksi $1 \mathrm{I}$ bioetanol diperlukan tepung $S$. duplicatum sebanyak 2,90 ton atau 41,40 ton $S$. duplicatum segar. Secara ekonomi, produksi bioetanol dari rumput laut coklat $S$. duplicatum dengan menggunakan teknologi yang dikembangkan dalam penelitian ini belum layak diterapkan.

\section{DAFTAR PUSTAKA}

Adams, J.M.M., Joseph, A.G., \& Lain, S.D. (2009). Fermentation study on Saccaharina latissima for bioethanol production considering variable pretreatments. J. Appl Phycol. 21: 569-574.

Adams, J.M.M., Toop, T.A., Donnison, I.S., \& Gallagher, J.A. (2011). Seasonal variation in Laminaria digitata and its impact on biochemical conversion routes to biofuels. Bioresource Technology. 102: 99769984. 
AOAC. (2005). Official Methods of Analysis of the Association of Analytical Chemist. Washington.

Anonymous. (2008). Sources of renewable energy. Sterling Planet, Inc. 24 November 2008. http:// www.sterlingplanet.com/index2.php. Diakses pada tanggal 9 Januari 2009.

Anonymous. (2009). CBS yeast database. http:// www.ncyc.co.uk/view_photo.php?yeast_id= CBS5830. Diakses pada tanggal 17 Februari 2009.

Anonim. (2014). Turunan selulosa dan aplikasinya dalam teknologi pangan. http://beranda-miti.com/ turunan-selulosa-dan-aplikasinya-dalam-teknologipangan. Diakses pada tanggal 10 Desember 2014.

Anonymous. (2015). Result. http://csmbio.csm.jmu.edu/ bioweb/Bio480/Fall05/MICROARRAY/Slekar2/ results.htm. Diakses pada tanggal 12 Februari 2015.

Arnata, I.W. (2009). Pengembangan Alternatif Teknologi Bioproses Pembuatan Bioetanol dari Ubi Kayu Menggunakan Trichoderma viride, Aspergilus niger dan Saccharomyces cerevisiae. Tesis. Program Pascasarjana Institut Pertanian Bogor, Bogor.

Ashriyani, A. (2009). Pembuatan Bioetanol dari Substrat Makroalga Genus Eycheuma dan Gracilaria. Skripsi. Departemen Kimia. Fakultas Matematika dan IImu Pengetahuan Alam. UI. Depok.

Bakare, M., Adewale, I., Ajayi, A., \& Shonukan, O. (2006). Purification and characterization of cellulase from the wild-type and two improved mutants of Pseudomonas fluorescens. African Journal of Biotechnology. 4(9): 898-904.

Borines, M.G., de Leon, R.L., \& Cuello, J.L. (2013). Bioethanol production from the marcoalgae Sargassum spp. Bioresources Tehcnology. 138: 2229.

Carvajal, M.V., Querol, A., \& Belloc, C. (2006). Identiûcation of species in the genus Pichia by restriction of the internal transcribed spacers (ITS1 and ITS2) and the 5.8S ribosomal DNA gene. Identification of Pichia species by 5.8S-ITS rDNA RFLP. Antonie van Leeuwenhoek. 90: 171-181.

Da Silva, R., Lago, E.S., Merheb, C.W., Machione, M.M., Park, Y.K., \& Gomes, E. (2005). Production xylanase and CMCase on solid state fermentation in different residues by Thermoascus auranticus Miehe. Braz J. Microbiomol. 36: 235-241.

Dubois, M., Gilles, K.A., Hamilton, J.K., Rebers, P.A., \& Smith, F. (1956). Colorimetric method for determination of sugars and related substances. Anal. Chem. 28: 350-356.

Gautam, S.P., Bundela, P.S., Pandey, A.K., Jamaluddin, Awasthi, M.K., \& Sarsaiya, S. (2010). Optimization of the medium for the production of cellulase by the Trichoderma viride using submerged fermentation. International Journal of Environmental Sciences. 1(4): 656-665.

Gunam, I.B.W., Aryanta, W.R., \& Darma, I.B.N.S. (2011). Produksi selulase kasar dari kapang Trichoderma viride dengan perlakuan konsentrasi substratampas tebu dan lama fermentasi. Jurnal Biologi. XV(2): 2933.
Harvey, F. (2008). Bioetanol Berbahan Dasar Ampas Rumput Laut. Under Graduate. Thesis. Bogor Agricultural University.

Hogg, S. (2005). Essential Microbiology. John Wiley \& Sons Ltd, England. 454 pp.

Horn, S.J., Aasen, I.M., \& Østgaard, K. (2000). Ethanol Production from Seaweed Extract. J. of Industrial Microbiology \& Biotechnology, 25: 249-254.

Horn, S.J. (2000). Bioenergy from Brown Seaweeds. Thesis. Department of Bioetechnology. Norwegian University of Science and Technology. 18 September 2008 .http://www.diva-portal.org/diva/ getDocument?urn nbn no ntnu diva-5471 fulltext.pdf. Diakses pada tanggal 14 Januari 2009.

Hyeon, J.Y., S.E. Lee, W.Y. Choi, D.H. Kang, H.Y. Lee, \& K.H. Jung. (2011). Repeated-batch operation of surface-aerated fermentor for bioethanol production from the hydrolysate of seaweed Sargassum sagamianum. J. of Microbiol. Biotechhnol. 21(3): 323-331.

Irawati, D. (2006). Pemanfaatan Serbuk Kayu untuk Produksi Etanol. Tesis. Program Pascasarjana, Institut Pertanian Bogor, Bogor.

Jenie, B.S.L. (1990). Kajian Teknik Imobilisasi Kapang Penghasil Selulase dan Asam Sitrat dalam Spons untuk Pemanfaatan menjadi Asam Sitrat. Disertasi. Program Pascasarjana, Institut Pertanian Bogor, Bogor.

Kadi, A. \& Atmadja, W.S. (1988). Rumput Laut (Algae): Jenis, Reproduksi, Produksi, Budidaya dan Pasca Panen. Puslitbang Oseanologi LIPI, Jakarta.

Kawaroe, M., Santoso, J., \& Adriani. (2012). Domestikasi dan Seleksi Makroalga Merah (Red Algae) sebagai Penghasil Bioethanol di Kepulauan Seribu, DKI Jakarta. Lembaga Penelitian dan Pengabdian kepada Masyarakat. IPB.

Kalimuthu, S. (1969). Variations in growth and mannitol and alginic acid contents of Sargassum myriocystum J. Agardh. http://eprints.cmfri.org.in/647/1/ Article_36.pdf. Diakses pada tanggal 10 Desember 2013.

Kim, G.S., Myung, K.S., Kim, Y.J., Oh, K.K., Kim, J.S., Ryu, H.J., \& Kim, K.H. (2007). Methode of Producing Biofuel using Sea Algae. World Intelectual Property Organization, Seoul.

Kloareg, B., Demarty, M., \& Mabeau, S. (1986). Polyanionic characteristic of purified sulphated homofucans from brown algae. Int. J. Biol. Macromol. 8: 380-386.

Loebis, E.H. (2008). Optimasi Proses Hidrolisis Kimiawi dan Enzimatis tandan Kosong Kelapa sawit menjadi Glukosa untuk Produksi Etanol. Tesis. Program Pascasarjana, Institut Pertanian Bogor, Bogor.

Mandels, M., Andreotti, R., \& Roche, C. (1976). Measurement of saccharifying cellulase. Biotechnol. Bioeng. Symp. 6: 21-23.

Miller, G.L. (1959). Use of dinitrosalicylic acid reagent for determination of reducing Sugar. Anal. Chem. 31(3): 426-428. 
Molla, A.H., Fakhru'l-Razi, A., \& Alam, M.Z. (2004). Evaluation of solid state bioconversion of domestic waste-water sludge as a promising environmental friendly dis-posal technique. Water Research. 38: 4143-4152.

Neethu, K., Rubeena, M., Sajith, S., Sreededi, S., Priji, P., Unni, K.N., Sarath Josh, M.K., Jisha, V. N. Pradeep, S., \& Benjamin, S. (2012). A novel strain of Trichoderma viride shows complete lignocellulolytic activities. Advances in Bioscience and Biotechnology. 3: 1160-1166.

Nenci. (2012). Isolasi dan Karakterisasi Selulase dari Trichoderma viride Strain T051 dengan Substrat Jerami. Skripsi. Fakultas Matematika dan IImu Pengetahuan Alam. Program Studi Kimia. Universitas Indonesia. Depok

Ota, A., Kawai, S., Oda, H., Iohara, K., \& Kousaku Murata K. (2013). Production of ethanol from mannitol by the Yeast Strain Saccharomyces paradoxus NBRC 0259. Journal of bioscience and bioengineering. 116(3): 327-332.

Pramanik, K. (2003). Parametrics studies on batch alcohol fermentation using Saccharomyces cerevisiae yeast extracted from Toddy. J. Chin. Inst. Chem. Engrs. 34 (4): 487-492.

Prihatini, R.I. (2008). Analisa Kecukupan Panas pada Proses Pasteurisasi Santan. Skripsi. Departemen Teknologi Industri Pertanian. Fakultas Teknologi Pertanian. Institut Pertanian Bogor, Bogor.

Quain, D.E. \& Boulton, C.A. (1987). Growth and metabolism of mannitol by strains of S. cerevisiae. J. Gen. Microbiol. 133: 1675-1684.

Ratnakomala, S. (2010). Produksi Enzim Selulase dari Trichoderma dan Streptomyces Indonesia Menggunakan Biomasa Lignosellulosa untuk Produksi Bioetanol. Laporan Akhir Kegiatan. Program Insentif Riset Peneliti dan Perekayasa LIPI.

Resita, E.T. (2006). Produksi Selo-Oligosakarida dari Fraksi Selulosa Tongkol Jagung oleh Selulase Trichoderma viride. Skripsi. Institut Pertanian Bogor.

Santi, R.A., Sunarti, T.C., Santoso, D., \& Triwisari, D.A. (2012). Komposisi kimia dan profil polisakarida rumput laut hijau. Jurnal Akuatika. 3(2): 105-114.

Sari, R.N. (2010). Kajian Proses Produksi Bioetanol dari Rumput Laut Coklat (Sargassum duplicatum). Tesis. Program Pascasarjana Institut Pertanian Bogor, Bogor.

Saparianti, E., Dewanti, T., \& Dhoni, S.K. (2012). Hidrolisis ampas tebu menjadi glukosa cair oleh kapang Trichoderma viride (kajian konsentrasi ampas tebu (Saccharum officinarum) dan lama fermentasi). J. Tek. Pert. 5(1): 1-10.

Saputra, D.R., Ridlo, A., \& Widowati, I. (2012). Kajian rumput laut Sargassum duplicatum J.G. Agardh sebagai penghasil bioetanol dengan proses hidrolisis asam dan fermentasi. Journal Of Marine Research. 1(2): 145-151.

Shofiyanto, M.E. (2008). Hidrolisis Tongkol Jagung oleh Bakteri Selulotik untuk Produksi Bioetanol dalam Kultur Campuran. Skripsi. Fakultas Teknologi Pertanian, Institut Pertanian Bogor, Bogor.

Siddhanta, A.K., Chhatbar, M.U., Mehta, G.K., Sanandiya, N.D., Kumar, S., Oza, M.D., Prasad, K., \& Ramavatar Meena, R. (2011). The cellulose contents of Indian seaweeds. J Appl Phycol. 23: 919-923.

Subekti, H. (2006). Produksi Etanol dari Hidrolisat Fraksi Selulosa Tongkol Jagung oleh Saccharomyces cerevisiae. Skripsi. Fakultas Teknologi Pertanian, Institut Pertanian Bogor.

Susilawati, D.N., Rosmimik, Saraswati, R., Simanungkalit, R.D.M., \& Gunarto, L. (2002). Koleksi, Karakterisasi, dan Preservasi Mikroba Penyubur Tanah dan Perombak Bahan Organik. Prosiding Seminar Hasil Penelitian Rintisan dan Bioteknologi Tanaman. Balai Penelitian Bioteknologi dan Sumberdaya Genetik Pertanian.

Tanti, Y.A., Jayanti, Y.R., Prima K.A., dan Girisuta, B. (2011). Fermentasi hidrolisat eceng gondok menjadi bioetanol menggunakan Pichia stipitis. Prosiding Seminar Nasional Teknik Kimia "Kejuangan". ISSN 1693-4393. Pengembangan Teknologi Kimia untuk Pengolahan Sumber Daya Alam Indonesia.

Van Dijken, J.P. \& Scheffers, W.A. (1986). Redox balances in metabolism of sugar by yeasts. FEMS Microbiol. 32: 199-224.

Voet, D., Voet, J.G., \& Pratt, C.W. (2006). Fundamentals of Biochemistry Life at The Molecular Level. John Wiley \& Sons, Inc, New York.

Waluyo, L. (2004). Mikrobiologi Umum. Penerbit Universitas Muhamadiyah Press. Malang. 372 p.

Widyaningsih, S. \& Diastuti, H. (2008). Pengaruh medium perendam terhadap sifat mekanik, morfologi, dan kinerja membran nata de coco. Molekul. 3(1): 28-33.

Wirahadikusumah, M. (1985). Biokimia. Metabolisme Energi, Karbohidrat dan Lipid. Penerbit ITB. Bandung, Bandung.

Yanagisawa, M., Nakamura, K., Ariga, O., \& Nakasaki, K. (2011). Production of high concentrations of bioethanol from seaweeds that contain easily hydrolyzable polysaccharides. Process Biochemistry. 46: 2111-2116.

Zhou, J.,Wang, Y.H., Chu, J., Zhuang, Y.P., Zhang, S.L., \& Yin, P. (2008). Identification and purification of the main components of cellulases from a mutant strain of Trichoderma viride T 100-14. Bioresour. Technol. 99: 6826-6833. 